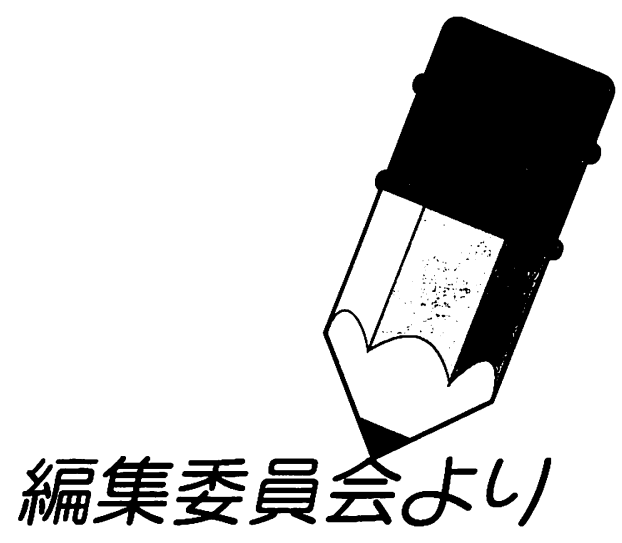

\section{0 月の定例編集委員会}

足例の編集委員会が 10 月 23 日（月）年後に学会事佫室で開 かれました、論説 24 篇, 稙都 6 篇, ノート1篇が紹介されま した。受理されたものは論説 2 篇，短報 2 篇およびノート 1 篇でしたか，わずかな修止あるいは著者の確認で受理される あのも数篇ありました. 見伍查読中の原稿は 26 篇で, 新しく 諭説 5 篇が投稿されてきております．相变わらず英文の少な い状況が続いておりますので, 皆梯からの英文原稿のご投稿 をお待ちしております。

今回とくに多くの原稿が綛介されましたが，それは例年 8 月に編集委員会を開いていないため，その後遣症ともいえる

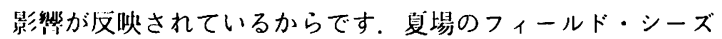
ンに, 野外调查や活外出張あるいは巡検などに会員の活動が 集ゆすることが多く，雑誌編集に関係する会員についてあ同 様な事情にあるために，8月の編集委員会を休むというのが これまでの慣例となっております。夏に遅れ気味となった編 集業䧄を，秋にとりかえすというのが見在の状況ということ

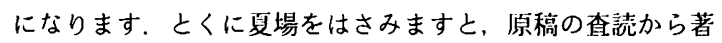
者への返送までに时間がかかりすぎ，せっかくご投稿下さっ た会員の皆梯にご迷惑をおかけすることが多々あります。そ うした事情ばかりでなく，奏際にはメールのやりとりだけで 遅くなってしまう場合もあります，編集委員会としてはでき るだけ早く处理すべく努力しているのですが，遅れておりま すことを潹くお託び申し上げる次第です。

川刊の雑誌を編集することは, 实は予想以上に大変な仕事 です．投稿原稿を専門委具や外部查読者に查読依頼すること にはじまり，原稿送付し，这ってきた查読結果を編集幹事が とりまとめて編集委員会で紹介し, それから通常は者者へ検 討をお願いします。編集委員会は每月 1 回ですので, 受付日 によってはここで 2 ヶ経過してしまうことがあります. 著 者からの戻り原稿を查読者または編集幹事がみて, 編集委員 会で確認後に印刷にまわりますが, 著者の確認がさらに必要 な点については再度倹討をお願いします。このような場合に は時間かかかかすぎて，遲いとのご批判をいただくことにな ります。また，内容に関してはあくまで著者の責任というの が然本ですので, 查読コメントに対しては著者の考えを理解 しやすいように主張していただきたくお願い申し上げます。 钎川の編集業務に関連する諸般の事情をご理解の上, あらた めてご協力下さいますよう重好てお願い申し上げます。

\section{次号予告（第 101 号第 12 号）}

論説

熊谷琢磨・紀藤典夫・艮澤好博: 北海道中軸帯二セウ居から 産出した始新世放散虫化石とフィッション・トラック年代

Tatsuki Tsujimori : Staurolite-bearing sillimanite schist cobble from the Upper Jurassic Tetori Group in the Kuzuryu area, Hida Mountains, central Japan

山北 聡- 伊藤谷生・田中秀奏・渡辺弘樹 : 古期中央構造線 としての佐志生断層の前期渐新世における top-to-thewest 斜め衝上運動

\section{副会長講演}

秋山雅彦 : 有機地質学一地質学における有機物研究のすすめ

短 報

坂島俊彦・山本啓司・岩松 唓 - 横田修一郎 - 竹下 徹 - 早 坂康隆: 熊本県八代市北東部竜峰山帯からのクロリトイド の発見

Satoko Suzuki : Metamorphic aragonite from the Mikabu and Northern Chichibu belts in central Shikoku, Southwest Japan : Indentification by Micro-area X-ray Diffraction analysis

ノ - r

高柳洋吉 : 生層序単元について

\section{0 月号の口絵についてのお詫ひと訂正}

発行後に, 写真を提供下さったアジア航測(株)から写真位 置についてご指摘いただきましたので，ここに訂正してお詫 び申し上げます. 1 ページ目の空中写真は右が北で, 2 ページ 目下の俯敟写真は上下が逆になっております.

記事に関しては校了時に急遽掲載となりましたので新聞報 道にもとづきましたが，地質調查所大阪地域地質センターの 鎌田浩毅氏より以下のようなご指摘がありましたので,ここ にお知らせいたします。

1.「九重山系」よりは学術論文題名に用いられる「九重火 山」が適当と考元られます。

2. 噴火の開始は 10 月 11 日夕刻とされています.

3.「硫黄山」は国土地理院発行の 1：50,000および 1： 25,000 地形図上にない地名で「星生山の東北東中腹にあ る通称硫黄山付近」が正確な表現です。

4. 古文書には 1738 年の噴火記録とされているものがあり ますが，これは硫黄山付近でやや規模の大きい噴気の突出 があったに過ぎないとも解釈可能であり，必ずしも今回の ような火山灰の噴出を意味するすのではありません.

5. 今回の噴火は基本的には水蒸気爆発によるものと考えて よいでしょうが，噴出した火山灰の中に今回新たに貫入し たマグマ起源のガラスが含まれているかどうかについて議 論がわかれており，現在検討がなされている最中です。

また，口絵「100万分の 1 大陸棚の海の基本図「南西諸島 東方」に見る日本南方海域の島弧海㴖系・背弧海盆の特 徵」の 4 ページ目第 6 図の説明文中に誤りがありましたの で,以下のように，お詫びして，訂正いたします．

1. 大東海嶺南面の南大東海盆に-40〜-60 $\mathrm{mGl}$ に達する 大きな負のフリーエア重力異常が分布ずること.

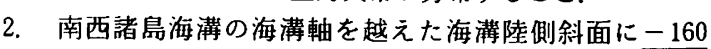
$\mathrm{mGl}$ に達する大きな負のフリーエア重力異常が分布する こと. 